\title{
蛍光砂を用いた高波浪イベント時における 底質移動動態に関する一考察
}

\author{
鈴木 崇之1・伊波 友生 2 -中村 由行 3 ・伴野 雅之4 \\ 1正会員 横浜国立大学准教授 大学院都市イノベーション研究院 \\ （†240-8501 神奈川県横浜市保土ヶ谷区常盤台79-5） \\ E-mail:suzuki-t@ynu.ac.jp \\ 2横浜国立大学 大学院都市イノベーション学府（†240-8501 神奈川県横浜市保土ヶ谷区常盤台79-5） \\ E-mail: inami-yuu-zc@ynu.jp \\ 3 正会員 横浜国立大学教授 大学院都市イノベーション研究院 \\ （邓240-8501 神奈川県横浜市保土ヶ谷区常盤台79-5） \\ E-mail:nakamura-y@ynu.ac.jp \\ 4正会員 港湾空港技術研究所主任研究官（テ239-0826 神奈川県横須賀市長瀬3-1-1） \\ E-mail: banno-m@pari.go.jp
}

\begin{abstract}
遡上域から砕波帯内外にかけての底質移動, および鉛直混合動態を明らかにすることを目的とし, 茨城県 波崎海岸において波浪計測，地形測量，および蛍光砂の投入を実施し，高波浪来襲後にコア採取を行った。 コアはX線CTスキャン実施後に細分割し, 蛍光砂採取, 粒度分析を行った。その結果, 地形測量により高 波浪に伴うバーの沖側への移動が確認されたが，バー周辺の蛍光砂の陸側への移動は見られず流速データ 等より底質は沿岸方向，および沖側に移動したと推測された。また，汀線付近に投入した蛍光砂はトラフ 部分まで移動していたがバーまでは到達しておらず，底質は汀線付近からバーまでの領域とバーから沖側 の領域において混合していないことが示唆された. 加えて, 高波浪時の底質移動にはトラフ部分の沿岸漂 砂の影響が大きいことが推察された.
\end{abstract}

Key Words : fluorescent sand, sediment movement, vertical mixing, storm, longshore current

\section{1. はじめに}

遡上帯から砕波帯内外にかけての領域は，活発な底質 移動が発生しており，これまでに各領域における移動機 構解明に向けて多くの研究がなされている.

海底表層の底質粒径に着目した研究では，加藤ら 1 )が 茨城県波崎海岸にて観測された地形断面と底質採取によ り，時化による底質のふるるい分け特性について報告して いる. また，柳嶋 ${ }^{213}$ 队同海岸での底質の分級と外力の 関連性について検討を行っている，蛍光砂を用いた現地 観測として, 灘岡ら 4)茨城県阿字ヶ浦海岸にて局所的 な底質移動方向と移動速度，鉛直混合過程を示している. また，遠藤ら ゆは太東海水浴場にて粒径ごとに色分けし た蛍光砂を投入し，粒径と漂砂量係数の関係性を示して いる.

底質の鉛直混合や堆積侵食履歷等の検討には，コアを 用いた解析が有用でありこれまでにも多くなされている。 山本らけは鹿島灘において取得したコアにより, 海浜の 堆積過程を推定している. 伴野らわも鹿島灘におけるコ アより採取された貝殼の年代を放射性炭素年代測定する
ことにより, 数十年から数百年の海底土砂の移動, 堆積 履歴を推定している. また, 大潟海岸おいても馬場・内 山衴によりコアによる底質空間分布の解析が行われてい る。一方，室内実験では，田中ら ${ }^{9}$ が大型造波水路を用 いた実験において，堆積性および侵食性の規則波条件下 における地形変化と分級過程を定量的に捉えている. 地 形変化時における底質内部構造の検討として，X線CTを 用いた解析も実施されている10). このように, 蛍光砂, コアを用いた検討は多くなされているものの，高波浪時 における遡上帯から砕波帯内外までの領域の漂砂体系を 一体的に解析し，地形形状や岸沖，鉛直底質移動特性を 考慮した砂移動メカニズムの解明に関する研究は数少な い.

そこで本研究では, 遡上帯から砕波帯内外にかけての 一帯を研究対象領域とし，蛍光砂の投入とコア採取によ り，高波浪イベント時における底質の岸沖，および鉛直 方向移動動態を明らかにすることを目的とした現地観測 を行った. 


\section{2. 現地観測の概要}

\section{(1) 現地観測地の概要}

本研究では，茨城県の波崎海岸に位置する独立行政法 人港湾空港技術研究所所有の波崎海洋研究施設 (Hazaki Oceanographical Research Station，HORS，図-1）にて現地調 査を実施した. HORS では週に 1 回，長さ $427 \mathrm{~m}$ の観測 栈橋に浴って地形断面測量が $5 \mathrm{~m}$ ピッチで行われている. 陸上部はスタッフとオートレベルを用いて測量し, 海域 部は質量 $3 \mathrm{~kg}$ のレッドを海底面まで降ろして測量を行っ ている. 当海岸を構成する砂の中央粒径は $0.18 \mathrm{~mm}$ であ $3^{1)}$. なお, 岸沖方向位置 $(x)$ はHORS 固有の座標軸で あり，地盤高の基準（D.L.）は波崎港工事基準面（T.P. $0.687 \mathrm{~m})$ とし，観測地点における干潮位，平均潮位，満 潮位はそれぞれ $-0.20 \mathrm{~m}, 0.65 \mathrm{~m}, 1.25 \mathrm{~m}$ である.

波浪データは，栈橋先端付近となる $x=303 \mathrm{~m}$ 地点に設 置された超音波式波高計によって得られたデータのうち, 毎正時をはさむ 20 分間を用いて算出された有義波高, 有義波周期を使用した。

\section{(2) 観測日程，および観測内容}

観測は，2014年10月19日から30日までの12日間実施し た.この期間中に行われた4回の地形測量結果を図-2に 示す．観測期間中にバーが沖側に約 $30 \mathrm{~m}$ 移動していた ことがわかる.

蛍光砂は, 中央粒径0.18 mmの波崎産の砂に5色の蛍光 塗料を塗装したものを使用した（図-3）。これらの蛍光 砂を，2014年10月19日，岸沖方向に概ね60mピッチに計5 箇所 $(x=65 \mathrm{~m}$, 桃色 ; $x=115 \mathrm{~m}$, 黄色 ; $x=180 \mathrm{~m}$, 青 色 ; $x=240 \mathrm{~m}$, 緑色; $x=320 \mathrm{~m}$, 赤色) に約 $225 \mathrm{~kg}$ ずつ海 底面に投入した（図-2中の丸印）。

栈橋上 $x=303$ m地点にて計測された波浪データを図-4 に示す．蛍光砂投入3日後の10月22日に，波高約 $2.5 \mathrm{~m}$ の 高波浪が来襲した。 その後，10月28日に再びやや高い波 浪が来襲したものの徐々に波高は低下し，静穏となった 10月30日にコア採取を実施した。

コア採取は，内径5 $2 \mathrm{~mm}$ (外径60 mm)，長さ $1.3 \mathrm{~m}$ ) 透明塩ビパイプを用いた. 採取箇所は，投入した蛍光砂 位置の概ね中間地点とし, 計8箇所において実施した（x $=0 \mathrm{~m}, 40 \mathrm{~m}, 80 \mathrm{~m}, 115 \mathrm{~m}, 150 \mathrm{~m}, 215 \mathrm{~m}, 270 \mathrm{~m}, 320 \mathrm{~m}$, 図-2の黒縦実線）。採取したコアの概要を表-1に示す. $x=0 \mathrm{~m}$ 地点は汀線よりも陸側の地点であるが，それ以外 は海中において潜水士による打ち込みにより採取した. 海中部にて採取したコアの平均長は $43.7 \mathrm{~cm}$ であった。

\section{3. 解析結果および考察}

採取したコアは，X線CTスキャン（LigheSpeed Ultra

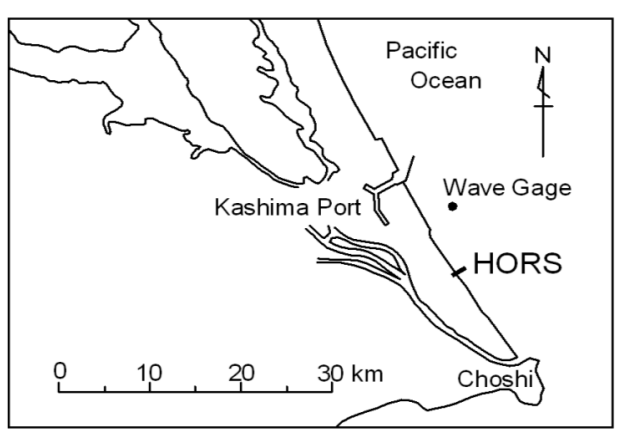

図-1 波崎海洋研究施設（HORS）の位置

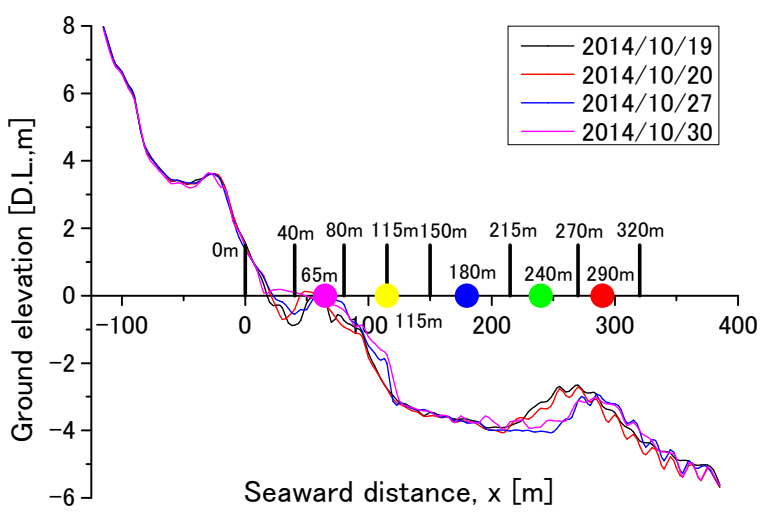

図-2 観測期間中の地形変化，および蛍光砂投入位置（丸印） とコア採取位置（黒縦実線）

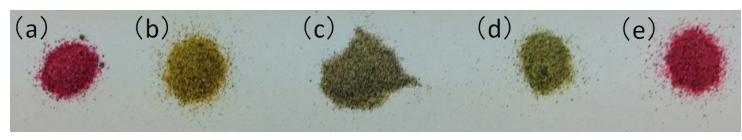

図-3 蛍光砂（a）桃，（b）黄, （c）青, （d）緑, （e）赤

表-1 採取したコアの概要

\begin{tabular}{c|r|r|r|r|r|r|r|r}
\hline $\begin{array}{c}\text { 地点 } \\
x[\mathrm{~m}]\end{array}$ & 0 & 40 & 80 & 115 & 150 & 215 & 270 & 320 \\
\hline $\begin{array}{c}コ \text { 長 } \\
{[\mathrm{cm}]}\end{array}$ & 77 & 40 & 50 & 42 & 52 & 30 & 46 & 46 \\
\hline 分割数 & 17 & 8 & 12 & 9 & 12 & 8 & 10 & 11 \\
\hline
\end{tabular}
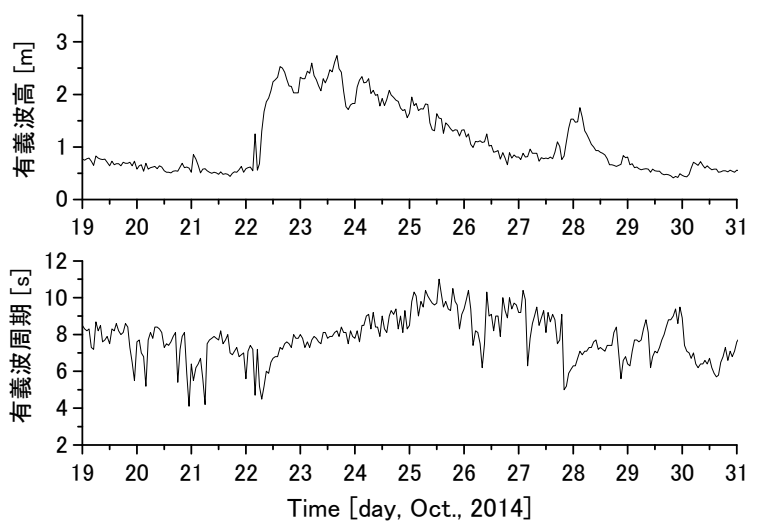

図-4 栈橋先端付近での有義波高，および有義波周期 
16GE，ヘルスケア・ジャパン(株)）による撮影を行った 画像は，X線の透過量の違いから，空間に占める密度の 高い場所は白く写り, 密度の低い場所は黒く写る.これ により, 目視による確認の困難な堆積構造や葉理面を把 握することができる.さらに，コアを半割したのち、コ ア連続撮影装置（(有)アルファーコム）による断面撮影 を行った.

この後, 蛍光砂の抽出と底質粒度分析のために各コア を表層から $5 \mathrm{~cm}$ 毎に分割した. 各コアの分割数を表-1に 示寸たただし，葉理面がある場合には適宜分割長を短く する対応を行った．始めに，小分けにされた各サンプル に含まれる蛍光砂数の計測を行った. 蛍光砂は, 分割し たサンプル毎に暗室においてブラックライトを当てなが ら抽出し，色別に個数を計測した．また，粒度分析に関 しては，連続全自動乾式音波子るい分け測定器（RPS205，(株)セイシン企業）を用いてサンプル毎に行った.

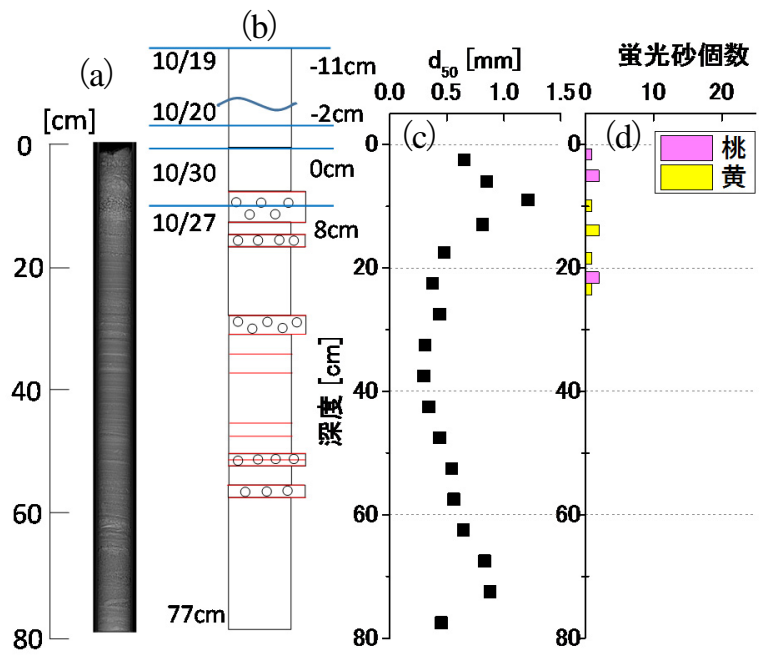

図-5 岸沖方向位置 $x=0 \mathrm{~m}$ における各計測結果の鉛直分布 (a) X線 CT画像, (b) 柱状図, (c) 底質中央粒径, (d) 蛍光砂数

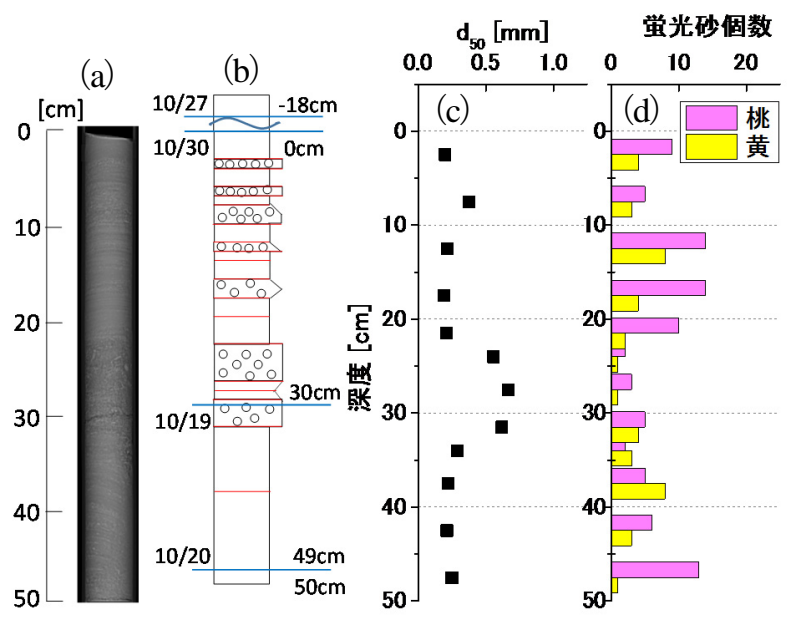

図-6 岸沖方向位置 $x=80 \mathrm{~m}$ における各計測結果の鉛直分布 （a）X線 CT 画像，（b）柱状図，（c）底質中央粒径, (d) 蛍光砂数
始めに，コア採取を実施した測点における解析結果， および考察を示す. 次に，今回解析を実施した遡上帯か ら硪波帯内外における底質の空間的移動動態について考 察する.

\section{(1) 各観測点における鉛直混合}

本項では，コア採取を実施した岸沖方向地点おける各 計測項目の鉛直分布（X線CT画像，柱状図，底質中央粒 径, 蛍光砂数）を示寸. 柱状図については, 半割後に目 視観察, およびX線CT画像より作成した. 柱状図中の赤 線は葉理面，青線は記載した日付に実施した地形測量に よって得られた海底面位置である。

\section{a) 岸沖方向 $x=0$ 地点}

$x=0 \mathrm{~m}$ での各鉛直分布を図-5に示寸. この地点は遡上 帯にあたり, コア取得時は汀線位置よりも陸側であった. 中央粒径は深度により変化しており, $10 \mathrm{~cm}$ 以浅にかけ てと70 cm以深に粗い層が存在していた. 蛍光砂につい ては, 桃色 $(x=65 \mathrm{~m}$ 投入 $)$ と黄色 $(x=115 \mathrm{~m}$ 投入 $)$ が20 cm以浅において確認できる. 黄色が確認されたことか ら100 m以上の岸向き底質移動が確認できた. 計4回計測 された地形断面よりも深い地点に蛍光砂が見られたこと から，高波浪時に少なくとも深度 $20 \mathrm{~cm}$ 辺りまで侵食さ れ，その後堆積したと推察できる.

\section{b) 岸沖方向 $\mathrm{x}=80 \mathrm{~m}$ 地点}

$x=80 \mathrm{~m}$ での各鉛直分布を図-6に示す．海底面より $5 \mathrm{~cm}$ から $10 \mathrm{~cm}$ と $20 \mathrm{~cm}$ から $35 \mathrm{~cm}$ にかけて粒径の粗い層が存在 していた. 蛍光砂は, 桃色 $(x=65 \mathrm{~m}$ 投入 $)$ と黄色 $(x=$ $115 \mathrm{~m}$ 投入）がコアの最下層からも採取された. これよ り, 高波浪が来襲した10月22日以降，この深度以深まで 侵食が進み, その後, 10月30日にかけて50 cm以上の堆 積が進んでいたことがわかる．採取された色は桃と黄の 2色のみであったことから, 高波浪イベント後の堆積で はバーあたりの底質はこの位置まで移流せず，遡上域か ら砕波帯内を移動していた底質であったと考えられる。

\section{c) 岸沖方向 $\mathrm{x}=115 \mathrm{~m}$ 地点}

$x=115 \mathrm{~m}$ での各鉛直分布を図-7に示寸．この地点の底 質は，粒径の鉛直変化が見られず全層でほぼ均一であり， その平均中央粒径は $0.18 \mathrm{~mm}$ であった。 また, 葉理面は 他の地点に比べて少なかった．蛍光砂は全層で採取され， 特に桃色 ( $x=65 \mathrm{~m}$ 投入) については全コアの中で最多 であり，特に深度 $20 \mathrm{~cm}$ から $40 \mathrm{~cm}$ において多く見られた。 海底面を見ると，20日に深度 $100 \mathrm{~cm}$ となっており，高波 浪後に一気に堆積が進んだと考えられる. 地形断面を見 ると（図-2），この地点から急激に水深が深くなり海底 勾配が急になっていることから，岸側から流れてきた底 質がこの場所に堆積した結果であると考えられる. 同地 点に投入した黄色の蛍光砂が少ないが，これは高波浪時 において拡散してしまったか，もしくは今回 $42 \mathrm{~cm}$ と十 
(a)

(b)

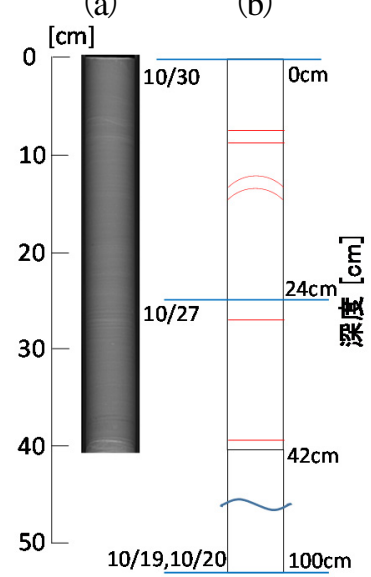

$\mathbf{d}_{50}[\mathrm{~mm}]$

巣光砂個数
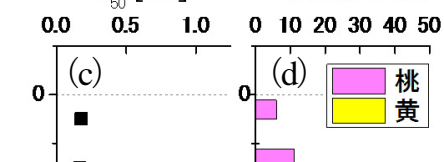

図-7 岸沖方向位置 $x=115 \mathrm{~m}$ における各計測結果の鉛直分布 （a） X線 CT 画像, （b）柱状図, (c) 底質中央粒径, (d) 蛍光砂数

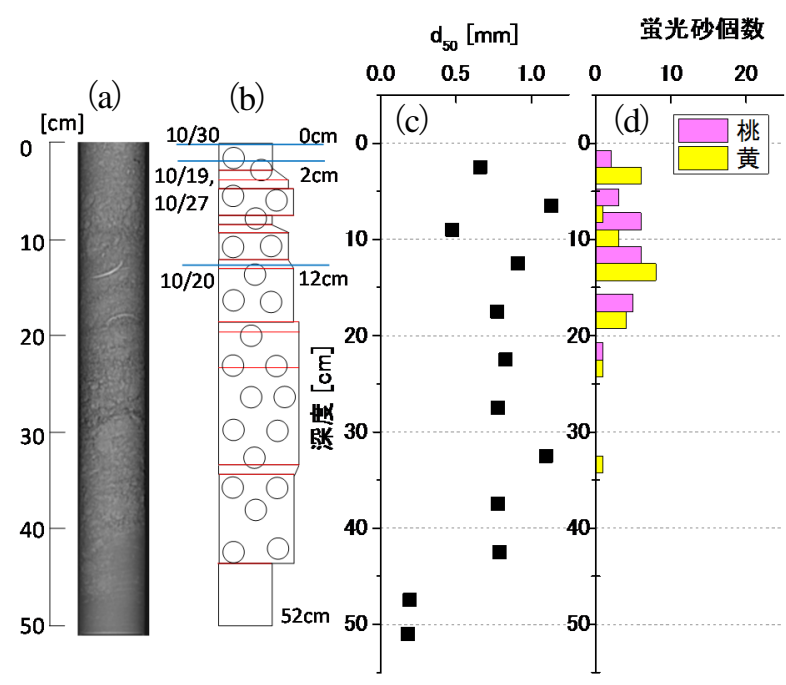

図-8 岸沖方向位置 $x=150 \mathrm{~m}$ における各計測結果の鉛直分布
(a) X線 CT 画像,
(b) 柱状図,
(c) 底質中央粒径,
(d) 蛍光砂数

(a)

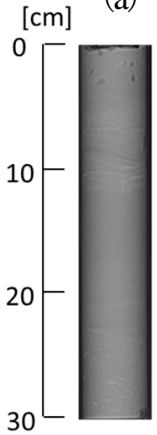

(b)

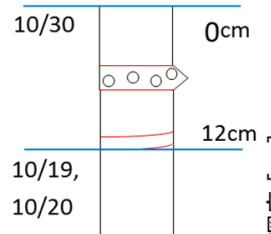

$\mathrm{d}_{50}[\mathrm{~mm}]$ 蛍光砂個数

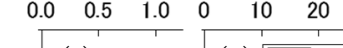

図-9 岸沖方向位置 $x=215 \mathrm{~m}$ における各計測結果の鉛直分布
(a) X線 CT 画像,
(b) 柱状図, (c) 底質中央粒径,

(d) 蛍光砂数

分なコア長が取得できなかったことから，より深い箇所 に堆積していることも考えられる.

\section{d) 岸沖方向 $x=150 \mathrm{~m}$ 地点}

$x=150 \mathrm{~m}$ での各鉛直分布を図-8に示す.この地点はバ 一手前のトラフにあたる（図-2）。深度 $40 \mathrm{~cm}$ 以浅にか けて粗い砂が堆積しており，その平均中央粒径は0.72 mmであった. 表層付近に粗い砂が堆積していたのはこ の地点のみである. $40 \mathrm{~cm}$ 以深は細砂が存在していた. 蛍光砂については，これまでと同様に桃色と黄色が確認 された. しかし，トラフ位置である $x=180 \mathrm{~m}$ に投入した 青色については確認されなかった. この考察は次項にて 行う. $35 \mathrm{~cm}$ 以深では蛍光砂は確認できなかったこと, また，トラフに位置しており地形変化も小さいことから この位置までは侵食されなかったと考えられる.

\section{e) 岸沖方向 $x=215 \mathrm{~m}$ 地点}

$x=215 \mathrm{~m}$ での各鉛直分布を図-9に示す．20 cm以深には やや粗い層が存在したものの葉理面はあまり見られなか った. $5 \mathrm{~cm}$ 以浅に存在する黒い斑点は貝殼である.ここ では桃色（ $x=65 \mathrm{~m}$ 投入） と黄色（ $x=115 \mathrm{~m}$ 投入）が採取 されたが， $x=150 \mathrm{~m}$ 地点と同様に $x=180 \mathrm{~m}$ 投入した青 色は確認されなかった. 桃色は $x=65 \mathrm{~m}$ 地点に投入して おり，少なくとも150 m沖方向に移動していたことがわ かつた。

\section{f) 岸沖方向 $x=270 \mathrm{~m}$ 地点}

$x=270 \mathrm{~m}$ での各鉛直分布を図-10に示す．本地点は，蛍 光砂投入時はバー頂部であったが，高波浪によりバーが 沖側に移動し大きく侵食が進んだ箇所である（図-2）. ここではこれまでと傾向が異なり，採取された色は緑 $(x=240 \mathrm{~m}$ 投入 $)$ と赤 $(x=290 \mathrm{~m}$ 投入 $)$ であった. 測量 結果からは判断できないが，蛍光砂がコアの最下層から も採取されていることから, 高波浪来襲前の20日の海底

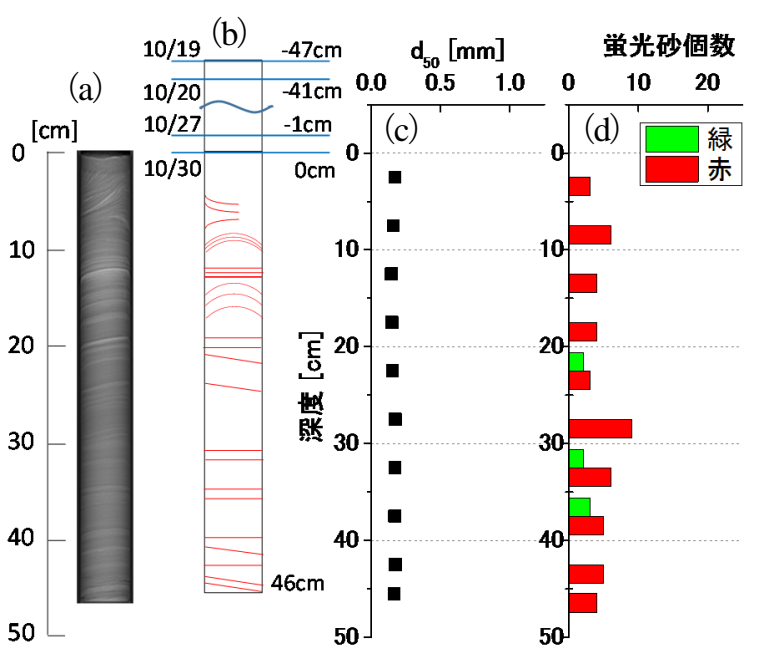

図-10 岸沖方向位置 $x=270 \mathrm{~m}$ における各計測結果の鉛直分布 （a）X線CT画像，（b）柱状図，（c）底質中央粒径，（d） 蛍光砂数 
面を基準にすると高波浪により少なくとも $93 \mathrm{~cm}$ 以上侵 食し, その後に $46 \mathrm{~cm}$ 以上堆積したといえる.この堆積 した層の底質粒径は全層に渡りほぼ均一であり, その平 均中央粒径は $0.16 \mathrm{~mm}$ であった. コアには多くの葉理面 が確認されたことから，時間スケールは不明であるが高 波浪後段階的に堆積が進んだと考えられる.

\section{（2）高波浪時における底質移動}

本項では，高波浪時における遡上帯から砕波帯内外で の底質移動について考察寸る. 解析期間における地形断 面変化とこの断面変化から算出した $5 \mathrm{~m}$ 毎の変化土量,

および蛍光砂取得数を図-11 に示寸. 図-11 (a)の地形断 面図中に示した丸印は，それぞれの色の蛍光砂投入地点 であり，また，鈆直黒太線はコア採取地点である。この 鉛直黒太線の長さはコア長に対応している．観測中の変 化土量は, $x=35 \mathrm{~m}, 110 \mathrm{~m}$ 辺りにおいて $21.1 \mathrm{~m}^{3}, 19.3 \mathrm{~m}^{3}$ 程度の堆積が進み, $x=255 \mathrm{~m}$ 一帯において $34.1 \mathrm{~m}^{3}$ 程度の 侵食であったことがわかる.

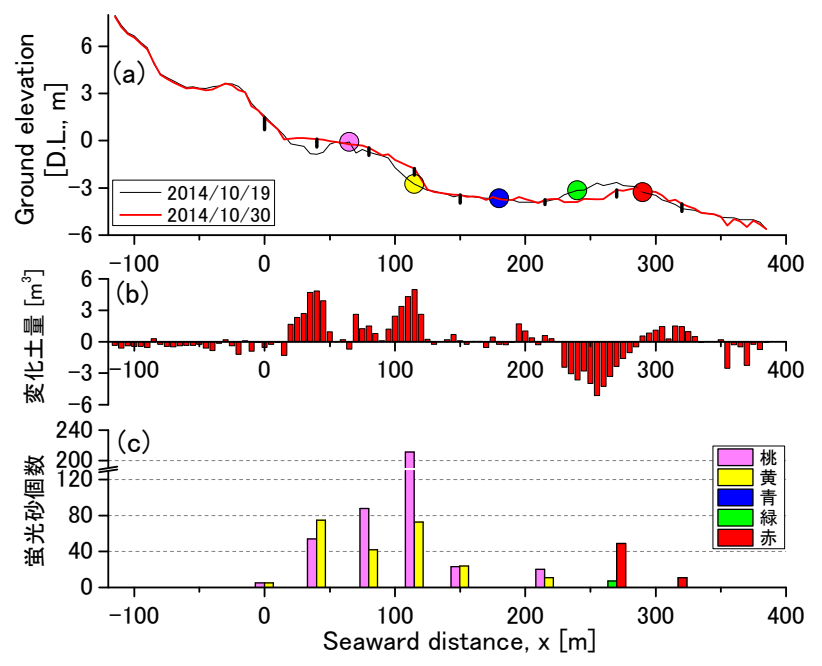

図-11 （a）解析期間における地形断面変化，（b）土量変化， (c) 蛍光砂数

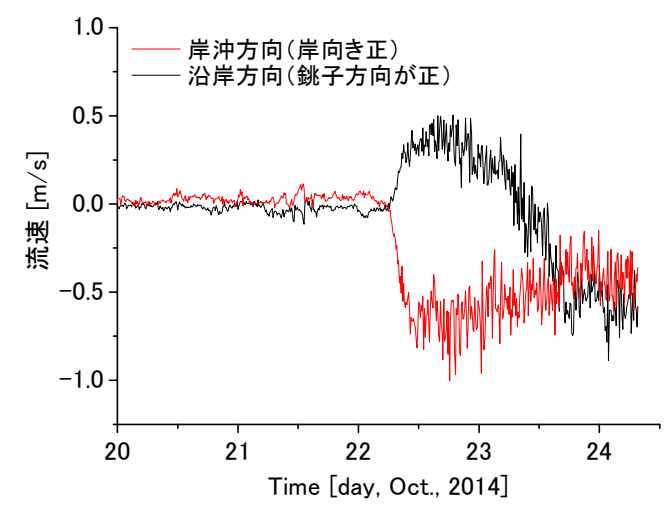

図-12 解析期間中岸沖方向位置 $x=245 \mathrm{~m}$ にて計測された岸沖方 流速と沿岸方向流速
バー頂部やや陸側の $x=245 \mathrm{~m}$ 地点（緑色の蛍光砂投入 地点よりも5 m沖側）に，波高計（AWH-USB，JFEアド バンテック(株)）と流速計（AEM-USB，JFEアドバンテ ック(株)）を固定させた小型アレイを設置していた．流 速計の計測地点は設置時の海底面上約 $0.7 \mathrm{~m}$ である. し かし，10月 22 日から続いた高波浪による地形変化によ り，24 日 7 時 50 分頃にアレイが流出している. この時 刻までの流速分布 (10 分間隔 2 分間平均值)を図-12 に 示寸，岸沖流速ついては岸向きを正，沿岸流速は銚子向 きを正としている（図-1）。図より，高波浪の来襲と共 に沖向きの流れが卓越していることがわかる．また，沿 岸流速に関しては，一度銚子方向に向いた流れが時間と 共に変化し，23 日 12 時ごろには逆向きに転じているこ とがわかった．この高波浪までの地形変化は小さいと考 えられることから（図-2），蛍光砂はある程度その場に 留まっていたと推測されるが，高波浪時の沿岸流，およ び岸沖方向の流れにより一気に移流したと考えられる.

$x=65 \mathrm{~m}$ に投入した桃色の蛍光砂は $x=0 \mathrm{~m}$ から $215 \mathrm{~m}$ ま でで確認することができた. 取得数から判断すると, 沖 向きの移動が支配的であったと考えられる. また， $x=$ $115 \mathrm{~m}$ で桃色の蛍光砂を特に多く確認できたことから, 沖向きの流れによる漂砂により, この辺りの堆積が進ん だと考えられる. 黄色 $(x=115 \mathrm{~m}$ に投入）の蛍光砂は, 桃色の蛍光砂と同样の領域で確認できた。 この同地点に 投入した黄色の個数が少ないが，これはコア長が短く, より深い部分に堆積していることも考えられる.

$x=180 \mathrm{~m}$ 地点に投入した青色の蛍光砂は，どのコアか らも採取できなかった．蛍光砂投入時，この位置はトラ フであり，この部分に生じていた沿岸流により岸沖方向 に加え沿岸方向にも移流した可能性が考えられる. $x=$ $240 \mathrm{~m}$ に投入した緑色の蛍光砂は，僅かであるが $x=270 \mathrm{~m}$ 地点でのみ確認できた. 緑色に関しても，青色と同椂に 沿岸方向に移流したと考えられる. バー頂部よりもやや 沖側に投入した赤色 $(x=290 \mathrm{~m})$ の蛍光砂は， $x=270 \mathrm{~m}$ と $320 \mathrm{~m}$ で確認できた. 沿岸流の分布は，バーよりも岸 側にて大きくなるが，その沖側では小さくなることから 11)，赤色の蛍光砂は青色や緑色に比べて投入箇所周囲に 留まっていたと考えられる. このことが， $x=215 \mathrm{mより}$ 岸側と $x=270 \mathrm{~m}$ より沖側において蛍光砂の取得色に顕 著な差が表れた理由と考えられる.

また，高波浪時の地形変化は主に岸沖漂砂が支配的と されているが，地形形状によっては沿岸漂砂の影響も大 きいことが示唆された.

\section{5. まとめ}

波崎海岸において, 波浪計測, 地形測量, および蛍光 砂の投入とコア採取により，高波浪時における底質移動 
動態について検討を行った。主な結論を以下に示す.

（1）地形測量による侵食堆積履歴と蛍光砂の取得状況 により，底質の岸沖移動，鉛直配分機構の検討が可能と なった。

（2）地形断面計測，およびコアのX線CTスキャン画像 により，同じ堆積においても葉理面の形成しながらの場 合とそうでない場合が確認された。

（3）高波浪時，底質は汀線付近からバーまでの領域と バーから沖側の領域において，それぞれの領域内のみに おいて移動をし，その領域におおよそ留まっていること が示唆された。 また，トラフ部分においては沿岸流の影 響が大きいことが推察された。

謝辞 : 本研究の観測を実施するにあたり，本学修士1年 栗原圭梧君，JSPS海外特別研究員Ahmad Nadeem氏に協力 頂いた。 また，底質粒度分析においては，港湾空港技術 研究所，柳嶋慎一氏にご協力頂いた．ここに謝意を表す る. 本研究は科研費若手研究（A）課題番号26709034, 特別研究奨励費課題番号26・04759の支援によるものであ る. また, 解析の一部は高知大学海洋コア総合研究セン ター共同利用研究（後期14B051）のもとで実施された.

\section{参考文献}

1) 加藤一正, 柳嶋慎一, 栗山善昭, 磯上知良, 村上裕幸, 藤田誠 : 砕波帯内の底質粒度の変動特性一波崎海洋研究 施設における現地調查一, 港湾技術研究所報告, 第 29 巻, 第 2号，pp.37-61，1990.
2) 柳嶋慎一 : 汀線付近における底質粒径の時空間変化に関 する現地調查, 海岸工学論文集, 第 52 巻, pp.401-405, 2005.

3) 柳嶋慎一：台風強大化に伴い砂浜海岸で想定される地形 変化と底質粒径変化に関する検討，土木学会論文集 B2, Vol.69, No2, pp.551-555, 2013.

4) 灘岡和夫，田中則男，加藤一正 : 蛍光砂を用いた砕波帯 内における局所的砂移動の観測，港湾技術研究所報告, 第 20 巻, 第 2 号, pp.75-126, 1981.

5) 遠藤将利, 小林昭男, 野志保仁 : 蛍光砂の追跡調査結果 に基づいた漂砂量の粒径依存に関する考察，平成 22 年度 日本大学理工学部学術講演会論文集, pp.649-650, 2012.

6) 山本幸次, 鳥居謙一, 笠井雅広, 佐藤愼司 : 柱状コアと 音波探査に基づく鹿島灘沿岸の堆積物特性の把握，海岸 工学論文集，第 47巻, pp.651-655, 2000.

7) 伴野雅之, 清家弘治，小松原純子，栗山善昭 : 放射性炭 素年代測定を用いた海底土砂の長期的移動・堆積履歴の 推定，土木学会論文集 B2，Vol.69，No2，pp.686-690，2013.

8) 馬場康之, 内山清 : 大潟海岸における平面地形および底 質のコアサンプリング調査, 京都大学防災研究所年報, 第 54 号 B，pp.633-638，2011.

9) 田中正博, 井上亮, 佐藤愼司, 磯部雅彦, 渡辺晃, 池野 正明，清水隆夫 : 2 粒径混合砂を用いた大型海浜断面実験 と粒径別漂砂量の算出, 海岸工学論文集, 第 47 巻, pp.551-555，2000.

10）山田文彦，立川龍太，辻本剛三，末長清也，Long B., Pilote C. : 医療用 X線 CTを用いた波作用下の地形変化・底 質輸送の同時連続計測，土木学会論文集 B2，Vol.68，No.2, pp.506-510, 2012.

11) Kuriyama, Y.: A one-dimensional parametric model for undertow and longshore current velocities on barred beaches, Coastal Engineering Journal, pp.133-155, DOI No: 10.1142/S0578563410002130, 2010.

(2015.3.18 受付)

\section{A STADY ON SEDIMENT MOVEMENT DURING A STORM USING FLUORESCENT SAND}

\section{Takayuki SUZUKI, Yu INAMI, Yoshiyuki NAKAMURA and Masayuki BANNO}

The field experiments were conducted at Hasaki Coast, Japan in order to investigate the sediment crossshore and vertical movements in the area of the swash zone to the offshore end of the surf zone. In the experiments, the fluorescent sand was installed on the coast for five locations from the swash zone to the offshore. After the storm pass through the site, eight vertical sand cores were collected. During the experiments, wave data, and ground elevation data were also collected. The cores are subdivided after scanning by an X-ray scanner, the vertical distributions of sediment diameter and the number of fluorescent sand are investigated. From the ground elevation survey, an offshore bar was moved offshore about $30 \mathrm{~m}$ due to the storm. The fluorescent sand that installed near the bar were not collected in the surf zone or swash zone. This fact indicates that the sand around the bar area was advected toward alongshore or offshore. The fluorescent sand that installed in the swash zone and surf zone were drifted toward the swash zone and the trough area. Therefore, it can be considered that the sand movements are separated onshore side and offshore side of the bar. Moreover, it is suggested that the sediment transport in the trough area during a storm is affected by the longshore current. 